\title{
Gambaran Pemeriksaan Ultrasonografi pada Pasien Struma di Bagian/SMF Radiologi RSUP DR. M. Djamil Periode Januari - Desember 2019
}

\author{
Irfan Fadilah ${ }^{1}$, Dina Arfiani Rusjdi', Dinda Aprilia ${ }^{3}$ \\ ${ }^{1}$ Program Studi Profesi Dokter Fakultas Kedokteran Universitas Andalas, Padang \\ ${ }^{2}$ Bagian Radiologi Fakultas Kedokteran Universitas Andalas/RSUP Dr. M. Djamil, Padang \\ ${ }^{3}$ Bagian IImu Penyakit Dalam Fakultas Kedokteran Universitas Andalas/RSUP Dr. M. Djamil, Padang
}

\author{
A B S T R A C T
}

\begin{abstract}
Latar belakang: Struma merupakan pembesaran dari kelenjar tiroid yang diakibatkan oleh kelainan kelenjar tiroid berupa gangguan fungsi atau gangguan dari susunan kelenjar dan morfologinya. Menurut WHO, angka kejadian struma masih cukup tinggi dengan defisiensi yodium sebagai penyebab utamanya.

Objektif: Penelitian ini bertujuan untuk mengetahui gambaran pemeriksaan ultrasonografi pada pasien struma di Bagian/SMF Radiologi RSUP DR. M. Djamil Periode Januari-Desember 2019. Metode: Penelitian ini merupakan penelitian deskriptif retrospektif yang menggunakan metode cross sectional dengan menggunakan data sekunder terhadap 123 pasien dengan kelainan struma tiroid yang memenuhi kriteria inklusi di RSUP DR. M. Djamil Padang periode Januari 2019-Desember 2019. Metode pengambilan sampel menggunakan teknik total sampling.

Hasil: Hasil Penelitian didapatkan 112 pasien dengan kelainan struma tiroid yang memenuhi kriteria inklusi. Hasil diagnosis klinis terbanyak adalah struma nodusa sebanyak 61 orang $(54,5 \%)$. Insidensi terbanyak ada pada rentang usia 41-50 tahun yakni 35 orang $(31,3 \%)$. Jenis kelamin terbanyak adalah perempuan 88 orang $(78,6 \%)$. Hasil ultrasonografi pasien struma terbanyak adalah difusa 43 orang (38\%).

Kesimpulan: Kelompok usia terbanyak dari pasien yang menderita struma adalah usia 41-50 tahun, mayoritas struma terjadi pada jenis kelamin perempuan dibandingkan dengan jenis kelamin laki-laki dan hasil gambaran ultrasonografi tiroid terbanyak adalah struma difusa.
\end{abstract}

Kata kunci: Kelainan tiroid, Struma tiroid, Ultrasonografi

\section{Apa yang sudah diketahui tentang topik ini?}

Struma merupakan pembesaran dari kelenjar tiroid yang diakibatkan oleh kelainan kelenjar tiroid berupa gangguan fungsi atau gangguan dari susunan kelenjar dan morfologinya. Angka kejadian struma masih cukup tinggi dengan defisiensi yodium sebagai penyebab utamanya.
Background: A goiter is an enlargement of the thyroid gland caused by abnormalities of the thyroid gland in the form of malfunctioning or disorders of the structure of the gland and its morphology. According to WHO, the incidence of goiter is still quite high with iodine deficiency as the main cause. Objective: This study aims to determine the description of ultrasound examinations in goiter patients in Department of Radiology DR. M. Djamil January-December 2019 period. Method: This research was a retrospective descriptive study using cross sectional method using secondary data on 123 patients with thyroid goiter who meet the inclusion criteria in RSUP DR. M. Djamil Padang period January 2019-December 2019. The sampling method used a total sampling technique. Result: The results showed that 112 patients with thyroid goiter disorders met the inclusion criteria. The most clinical diagnosis results were goiter nodusa as many as 61 people (54.5\%). The highest incidence was in the age range 41-50 years with 35 people (31.3\%). The most gender was 88 women (78.6\%). The results of ultrasonography in most goiter patients were diffuse in 43 people (38\%).

Conclusion: The conclusion of this study, it was found that the most age group of patients suffering from goitre were 41-50 years old, the majority of goiters occurred in the female compared to the male and the results of the most thyroid ultrasound images were diffuse goiter

Keyword: Thyroid Disorders, Goiter, Ultrasound

Apa yang ditambahkan pada studi ini?

Gambaran struma dari hasil diagnosis dokter dan gambaran ultrasonografi berdasarkan kelompok usia dan jenis kelamin 
ARTICLE INFORMATION

Received:November, $10^{\text {th }}, 2020$

Revised: July, $23^{\text {th }}, 2021$

Available online: July, $30^{\text {th }}, 2021$

\section{Pendahuluan}

Tiroid merupakan kelenjar endokrin yang terletak di bawah leher, yang menghasilkan hormon tiroid utama yaitu tiroksin (T4) dan triyodotironin (T3). Hormon T4 dan T3 terikat dalam darah dengan protein khusus yang mengikat T4 dan T3, yaitu thyroxyne binding globulin (TBG) dan thyroxine binding prealbumin (TBPA) dan hanya satu persen hormon yang tidak terikatberada dalam bentuk bebas (free) sehingga disebut FT4 dan FT3 yang berperan dalam mengendalikan metabolisme tubuh. Kadar hormon tiroid akan selalu berada pada range normalnya dikarenakan adanya feedback terhadap hormon Thyroid Stimulating Hormone (TSH) di hipofisis anterior yang mengatur dalam pertumbuhan sel tiroid, sintesis serta sekresi dari hormon tiroid. Pada keadaan tertentu, hormon TSH mengalami peningkatan dan penurunan yang abnormal. Keadaan ini lah yang mengakibatkan terjadinya pertumbuhan kelenjar tiroid abnormal dan memicu terbentuknya struma pada kelenjar tiroid.1,2,3,4

Struma atau biasa yang disebut dengan goiter merupakan suatu pembesaran dari kelenjar tiroid yang diakibatkan oleh kelainan kelenjar tiroid berupa gangguan fungsi atau gangguan dari susunan kelenjar dan morfologinya dimana gangguan tersebut menginduksi sel dari kelenjar tiroid untuk melakukan pembelahan sel yang terus menerus sehingga bentuk dari kompensasinya ialah terjadinya peningkatan volume (hipertrofi dan hiperplasi) dari kelenjar tiroid. Selain itu, hormon yang dihasilkannya dapat dijadikan nilai toksisitas yang mana nontoksik terjadi pada keadaan hormone tiroid yang rendah dan tidak menimbulkan gejala sedangkan toksik pada hormon tiroid yang tinggi serta diiringi dengan gejala. ${ }^{5}$

Penyebab paling umum dari struma di seluruh dunia ialah defisiensi yodium. Menurut WHO, 1,6 miliar orang berisiko mengalami gangguan defisiensi yodium dan diantaranya terdapat 655 juta yang struma dimana 27\% terdapat di Asia Tenggara. ${ }^{6}$ Dalam penelitian Wicham dari Britania Raya, 16\% populasi memiliki struma. Di Finlandia, pemeriksaan tiroid menggunakan USG pada 239 pasien struma didapatkan echo abnormalitas pada 69 pasien dengan 39 nodul soliter, 15 multipel nodul dan 15 pasien dengan difusa. ${ }^{7}$ Sedangkan pada penelitian pasien struma tiroid paska dilakukan tindakan operasi dengan menggunakan USG di Kangbuk Samsung Korea didapatkan 69 pasien dengan nodul dan 11 pasien dengan kista tiroid.8 Di Amerika, 61 pasien yang teraba nodul kemudian dilakukan pemeriksaan ultrasonografi ditemukan 35 pasien dengan tiroiditis Hashimoto. Rasio dari kejadian struma di dunia antara perempuan dan laki-laki 4:1 dan frekuensi kejadian struma difusa berkurang dengan bertambahnya usia. ${ }^{2}$

Di Sumatera Barat, data statistik kasus struma yang diakibatkan oleh defisiensi yodium belum tersedia, namun menurut data statistik hipertiroid yang dikeluarkan oleh Riskesdas 2013 jumlah perkiraan penduduk yang terkena hipertiroid pada usia $\geq 15$ tahun untuk wilayah Sumatera Barat berjumlah 10.283 jiwa dari total penduduk usia $\geq 15$ tahun 3.427 .772 jiwa. $^{9}$

Modalitas utama dalam penegakan diagnosis tiroid ialah dengan pemeriksaan menggunakan ultrasonografi. Berdasarkan penelitian tentang studi diagnostik pemeriksaan ultrasonografi dibandingkan dengan pemeriksaan histopatologi di RSUP Dr. Kariadi Semarang didapatkan sensitivitas USG sebesar 51,72\%, spesifisitas sebesar 86,2\%, nilai duga positif sebesar $78,94 \%$ dan nilai duga negatif sebesar $64,1 \%$.

Ultrasonografi dapat mendeteksi, menetapkan dan mengikuti ukuran struma, konsistensi, dan nodularitas sertadapat digunakan untuk melokalisasi nodul untuk dibiopsi yang dipandu secara ultrasonografi. Kelly dkk, dalam studi yang dilakukannya di Kanada menunjukkan bahwa pada beberapa pasien dengan struma multinodular, ultrasonografi juga dapat menilai risiko neoplasia secara efektif daripada dengan biopsi aspirasi jarum halus. ${ }^{2,10}$

\section{METODE}

Penelitian ini merupakan penelitian deskriptif retrospektif yang menggunakan metode cross sectional dengan cara mengumpulkan data 
dari rekam medis pasien dengan kelainan struma tiroid di RSUP Dr. M. Djamil Padang periode Januari 2019-Desember 2019. Jenis penelitian adalah studi observasional dengan desain cross sectional.

Penelitian dilakukan di bagian/SMF Radiologi di RSUP DR. M. Djamil Padang pada bulan Januari - November 2020.

Populasi penelitian ini adalah seluruh pasien dengan diagnosis klinis struma di bagian/SMF Radiologi RSUP DR. M. Djamil Padang periode Januari 2019-Desember 2019.

Sampel penelitian ini adalah seluruh populasi yang diambil dengan metode total sampling dan memenuhi kriteria inklusi dan kriteria eksklusi. Kriteria inklusi: Semua rekam medis pasien dengan diagnosis klinis struma yang melakukan pemeriksaan USG di bagian/SMF Radiologi RSUP Dr. M. Djamil Padang periode Januari 2019 - Desember 2019. Kriteria ekslusi: Pasien yang tidak memiliki data lengkap pada pemeriksaan USG, dan pada pemeriksaan USG masih terdapat diagnosis banding dari ekspertise.

Data yang didapatkan akan dianalisis secara statistik berdasarkan variabel yang dinilai menggunakan sistem komputerisasi yaitu analisis univariat. Analisis univariat dilakukan untuk mendapatkan penjelasan atau deskripsi dari suatu karakteristik tiap variabel yang diteliti, yakni karakteristik dari struma tiroid dan data ini disajikan dalam bentuk diagram dan tabel distribusi frekuensi

.Penelitian ini telah lulus kaji etik dengan nomor surat: 266/KEPK/2020.

\section{Hasil}

Berdasarkan hasil penelitian tentang gambaran ultrasonografi pada pasien struma di bagian radiologi RSUP Dr. M. Djamil Padang tahun 2019 didapatkan 123 orang sampel yang terdiagnosis dengan kelainan struma tiroid RSUP Dr. M. Djamil Padang, setelah dilakukan penelitian, didapatkan 112 dengan diagnosis dokter pengantar, hasil radiologi yang masih memiliki diagnosis banding ekspertise serta data yang tidak lengkap berdasarkan jenis kelamin, usia saat menderita struma, dan hasil gambaran ultrasonografi.
Tabel 1 Hasil diagnosis struma tiroid

\begin{tabular}{ccc}
\hline Diagnosis Struma Tiroid & Frekuensi (n) & $\mathbf{\%}$ \\
\hline Difusa & 51 & 45,5 \\
Nodusa & 61 & 54,5 \\
Total & 112 & 100 \\
\hline
\end{tabular}

Berdasarkan Tabel 1, didapatkan hasil diagnosis klinisnya tertera pada surat pengantar pemeriksaan radiologi oleh dokter pengirim kepada bagian/SMF Radiologi RSUP Dr. M. Djamil sebagian besar merupakan nodusa yakni sebanyak 61 orang $(54,5 \%)$ dan difusa sebanyak 51 orang $(45,5 \%)$.

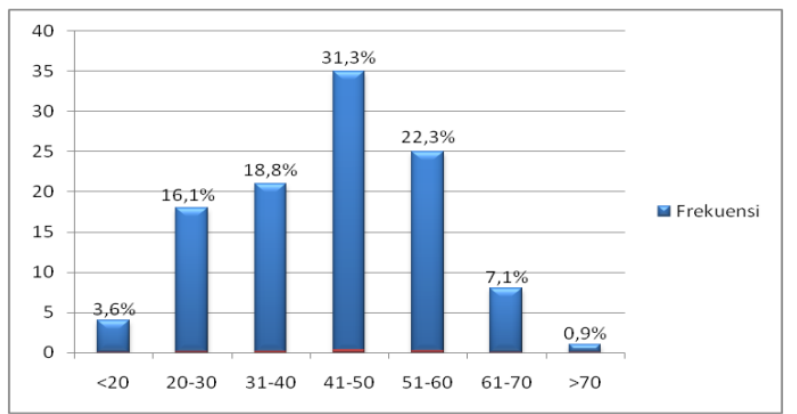

Gambar 1 Gambaran berdasarkan kelompok usia

Berdasarkan Gambar 1, didapatkan bahwa kasus struma tiroid paling tinggi insidensinya adalah pada usia 41-50 tahun, sebanyak 35 orang $(31,3 \%)$. Usia lanjut $>70$ tahun menunjukkan insidensi yang paling rendah sebanyak $1(0,9 \%)$ orang.

Tabel 2 Hasil Gambaran Ultrasonografi Berdasarkan Jenis Kelamin

\begin{tabular}{ccc}
\hline Jenis Kelamin & Frekuensi (n) & \% \\
\hline Laki-laki & 24 & 21,4 \\
Perempuan & 88 & 78,6 \\
\hline Total & 112 & 100 \\
\hline
\end{tabular}

Berdasarkan Tabel 2, didapatkan jenis kelamin pasien struma tiroid di Bagian/SMF Radiologi RSUP Dr. M. Djamil sebagian besar merupakan perempuan sebanyak 88 orang $(78,6 \%)$ dan laki-laki sebanyak 24 orang $(21,4 \%)$. 


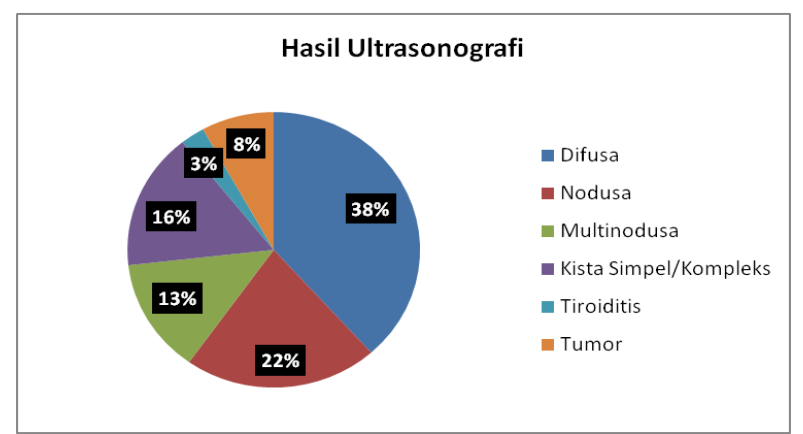

Gambar 2 Hasil gambaran ultrasonografi struma di bagian/SMF Radiologi RSUP DR M. Djamil Padang tahun 2019

Seperti tampak pada gambar 2, didapatkan hasil ultrasonografi pasien struma terbanyak terletak pada difusa sebanyak 43 orang (38\%), kemudian disusul dengan nodusa 24 orang (22\%), kista simpel/kompleks 18 orang (16\%), multinodusa 15 orang (13\%), tumor 9 orang (8\%), dan yang paling sedikit pada tiroiditis 3 orang $(3 \%)$.

\section{Pembahasan}

Struma merupakan bentuk temuan fisik dari pemeriksaan fisik yang dilakukan oleh dokter. Ada berbagai macam interpretasi hasil pemeriksaan kelainan tiroid oleh dokter diantaranya hipertiroidisme, hipotiroidisme, tiroiditis, tumor tiroid dan struma. Yang menjadi fokus peneliti ialah hasil pemeriksaan struma, dimana struma itu sendiri dalam interpretasinya terbagi menjadi dua (2) bentuk yaitu difusa dan nodusa. Hasil diagnosis awal dokter menjadi dasar untuk melakukan pemeriksaan penunjang berupa ultrasonografi dan umumnya struma ditemukan melalui pemeriksaan fisik oleh dokter. ${ }^{11}$

Pada penelitian ini, hasil diagnosis oleh Dokter pengirim pada struma tiroid sebelum dikirim ke bagian/SMF Radiologi Dr. M. Djamil Padang didapatkan nodusa terbanyak yakni sebanyak 61 orang $(54,5 \%)$ dan difusa sebanyak 51 orang $(45,5 \%)$. Hal ini juga serupa dengan penelitian yang dilakukan oleh Gannon, dkk (2018), dari tahun 2009 sampai 2013 di Philadelphia terhadap 236 pasien yang menjalani pemeriksaan ultrasonografi, 152 orang (64,5\%) didapatkan struma dari pemeriksaan fisik dan hanya 34,5\% ditemukan secara kebetulan pada pemeriksaan ultrasonografi dan 152 pasien pemeriksaan fisik tersebut ditemukan struma nodusa sebanyak 92 orang dan 60 orang yang struma difusa. ${ }^{11}$

Hal ini didukung dengan penelitian studi cohort yang dilakukan Kitaha, dkk (2019), dari tahun 1978 sampai 2013 di Denmark terhadap $8,258,807$ pasien dengan kelainan struma menunjukkan bahwa pada pemeriksaan awal oleh dokter terhadap struma didapatkan 65,782 orang terdiagnosis struma nodusa sedangkan 11,582 yang struma difusa. ${ }^{12}$

Angka kejadian struma tiroid, kasus yang paling tinggi berada pada rentang usia 41-50 tahun, sebanyak 35 orang (31,3\%) dan kasus yang paling rendah berada pada rentang usia lanjut $>70$ tahun yakni sebanyak 1 (0,9\%) orang. Menurut Knudsen, dkk (2002), umur memiliki korelasi terhadap angka kejadian struma dan mereka berpendapat seiring dengan bertambahnya umur kemampuan manusia dalam meng-uptake yodium berkurang terlebih lagi pada umur 40 tahun ke atas. ${ }^{13}$ Pendapat ini diperkuat dengan penelitian yang dilakukan oleh Vanderpump (2011), menemukan bahwa kejadian prevalensi struma meningkat seiring bertambahnya umur dan puncak prevalensi terjadinya struma berada pada fase pre-menopause pada perempuan yakni diatas umur 40 tahun. ${ }^{14} \mathrm{Hal}$ ini disebabkan karena daya tahan tubuh dan imunitas seseorang yang semakin menurun seiring dengan bertambahnya usia dan meningkatnya kebutuhan terhadap asupan yodium. Frekuensi struma meningkat seiring dengan usia. ${ }^{13,14}$

Berbeda dengan penelitian yang dilakukan Malboosbaf, dkk (2012), mereka mendapatkan struma berada pada kisaran umur 15-20 tahun. Kejadian struma pada umur 15-20 tahun berkaitan dengan masa pubertas dimana adanya perkembangan seks sekunder pada remaja sehingga diduga ada kaitan dengan masa pubertas dan peran hormon seks steroid. ${ }^{15}$ Pada masa pubertas, kebutuhan akan asupan yodium meningkat. Hal ini terjadi sebagai kompensasi dari adanya peningkatan pada growth hormone (GH) dan insulin-like growth factor I (IGF-I). Kedua hormon tersebut dapat memodulasi hormon TSH, dan pada masa pubertas terjadi perubahan profil hormon seks steroid yang mana hormon seks itu sendiri dapat mempengaruhi produksi hormon tiroid dikarenakan terdapat reseptor hormon seks pada organ tiroid. ${ }^{16}$ 
Jenis kelamin pasien struma tiroid di Bagian/SMF Radiologi RSUP DR. M. Djamil sebagian besar merupakan perempuan sebanyak 88 orang $(78,6 \%)$ dan laki-laki sebanyak 24 orang $(21,4 \%)$ dengan perbandingan 3,7:1. Hal ini mendekati dengan penelitian yang dilakukan oleh Tumbridge dkk (1977), rasio perbandingan yang didapatkan pada pasien struma tiroid antara perempuan dan laki-laki 4:1. Menurut Fleury, dkk (2001), dalam studi ekperimental jenis kelamin mempunyai pengaruh dalam angka kejadian struma. ${ }^{17} \mathrm{Hal}$ ini dikarenakan hormon seks steroid mampu memodulasi aksis hipotalamus-hipofisistiroid dalam mengeluarkan hormon tiroidnya dimana pemberian hormon estrogen memicu TRH untuk merangsang pengeluaran $\mathrm{TSH}$, sehingga TSH mendorong meningkatnya ikatan protein globulin dengan T4, dan peningkatan aktivitas 5deiodinase. ${ }^{18,19}$ Perempuan memiliki hormon estrogen yang mampu meningkatkan kadar thyroid binding globulin (TBG) yang bekerja sebagai transpor T4 dan T3 dalam darah sehingga terjadi penurunan kadar $\mathrm{T} 4$ bebas dan $\mathrm{T} 3$ bebas. Hal ini menstimulasi TSH sehingga terjadi hiperplasia kelenjar sebagai mekanisme kompensasi membentuk lebih banyak hormon tiroid agar kadar T4 dan T3 serum dapat kembali normal. ${ }^{20,21,22}$

Hasil gambaran ultrasonografi struma terbanyak terletak pada difusa sebanyak 43 orang (38\%), kemudian disusul dengan nodusa 24 orang (22\%), kista simpel/ kompleks 18 orang (16\%), multinodusa 15 orang (13\%), tumor 9 orang (8\%), dan yang paling sedikit pada tiroiditis 3 orang (3\%). Berbeda dengan hasil pemeriksaan fisik, struma difusa pada ultrasonografi menempati urutan yang pertama. Tingginya difusa disebabkan oleh banyak faktor, salah satunya terletak pada rendahnya sensitivitas pada diagnosis oleh dokter melalui pemeriksaan fisik. Pemeriksaan fisik dengan palpasi memiliki sensitivitas $10-41 \%$ dan dalam faktanya diagnosis hasil dari pemeriksaan fisik banyak berubah ketika dilakukan pemeriksaan ultrasonografi. Hal ini dikarenakan pada pemeriksaaan fisik, dokter hanya bisa memperkirakan bentuk difusa dan nodusa sedangkan difusa dan nodusa dalam pemeriksaannya memiliki banyak bentuk yang hanya bisa dilihat melalui ultrasonografi. Selain itu, pemeriksaan fisik dengan palpasi hanya dapat meraba ukuran nodul $>10 \mathrm{~mm}$ sehingga sulit dapat terdeteksi ketika nodul berukuran $<10 \mathrm{~mm}$ sedangkan dengan ultrasonografi, nodul padat sekecil $3 \mathrm{~mm}$ dan nodul kista $2 \mathrm{~mm}$ dapat dengan mudah terdeteksi menggunakan ultrasonografi. ${ }^{23}$ Penelitian yang dilakukan oleh Mehmet, dkk (2002), dari 261 pasien yang didiagnosis difusa tiroid melalui pemeriksaan fisik, ditemukan 82 (31,5\%) pasien memiliki nodul tunggal dan 155 $(59,2 \%)$ pasien memiliki gondok multinodular dengan ultrasonografi. Sedangkan pada 460 pasien yang didagnosis nodusa tiroid melalui pemeriksaan fisik, didapatkan 258 (56\%) memiliki lebih dari satu nodul. ${ }^{24}$ Hasil penelitian ini menunjukkan pentingnya ultrasonografi terutama untuk pasien yang dievaluasi memiliki gondok difus atau nodul tunggal sehubungan dengan adanya nodul yang tidak terdeteksi oleh pemeriksaan fisik. Faktor lain penyebab tingginya difusa disebabkan karena kurangnya intake dari yodium. Penelitian yang dilakukan oleh Elahi, dkk (2005), mendapatkan dari 350 orang remaja diduga mengalami kelainan tiroid pada pemeriksaan fisik oleh dokter yang kemudian dilanjutkan dengan pemeriksaan melalui ultrasonografi, didapatkan sebanyak 212 orang $(60,6 \%)$ mengalami struma difusa dan diduga asupan yodium yang menjadi penyebabnya. ${ }^{25}$ Pendapat yang serupa dikemukakan oleh Dodd, dkk (1993), dari 866 remaja kelainan tiroid didapatkan struma sebanyak 485 (86\%) dan kurangnya intak yodium menjadi faktor tingginya hasil struma pada penelitian tersebut. ${ }^{26}$ Kurangnya asupan yodium berefek pada peningkatan sensitifitas reseptor TSH dan memengaruhi faktor pertumbuhan yang terlibat dalam perkembangan dan pertumbuhan tiroid didalam tubuh, akibatnya terjadi pertumbuhan yang difus pada organ tiroid. ${ }^{17}$

Struma nodusa menempati urutan kedua dan kebanyakan struma nodusa pada diagnosis awal, ketika dilakukan pemeriksaan ultrasonografi berubah kepada multinodusa dan keganasan seperti tumor dan kista simpel/kompleks sehingga yang awalnya nodusa terbanyak pada diagnosis awal berubah menjadi yang kedua setelah difusa. Hal ini sesuai dengan penelitian yang dilakukan Gannon, dkk (2018), mereka menemukan bahwa dari 152 pasien didapatkan 92 pasien teraba nodul dan ketika 
dilakukan pemeriksaan penunjang berupa ultrasonografi 68 nodul pasien ditemukan keganasan seperti kistik dan tumor. ${ }^{11}$ Penelitian serupa juga dilakukan oleh Moon, dkk (2008) dimana dari 849 pasien yang teraba nodul dilakukan pemeriksaan ultrasonografi didapatkan 360 pasien nodul ganas, dan 489 pasien nodul jinak dengan 429 pasien nodul hiperplasia, 46 pasien adenoma folikuler, 14 pasien tiroiditis. ${ }^{27}$ Risiko keganasan pada nodul tiroid meningkat seiring dengan meningkatnya hormon TSH. hormon TSH memiliki peranan penting dalam regulasi fungsi dari organ tiroid seperti produksi hormon tiroid, pertumbuhan dan perkembangan sel tiroid dan peranan dalam terbentuknya nodul pada tiroid. Proliferasi sel tiroid bergantung pada hormon TSH, begitu pula terbentuknya nodul pada tiroid dan diferensiasi sel kanker tiroid akibat dari tingginya hormon TSH di dalam tubuh. ${ }^{28,29,30}$

\section{Simpulan}

Berdasarkan hasil penelitian ini didapatkan kesimpulan bahwa hasil diagnosis oleh dokter pengirim ke bagian/SMF Radiologi Dr. M. Djamil didapatkan nodusa terbanyak. Kelompok usia terbanyak dari pasien yang menderita struma adalah usia dewasa (41-50) tahun. Mayoritas struma terjadi pada jenis kelamin perempuan dibandingkan dengan jenis kelamin laki-laki. Hasil gambaran ultrasonografi tiroid terbanyak terletak pada struma difusa.

\section{Daftar Pustaka}

1. Sherwood L. In: Herman 00, Albertus AM, Dian R editors. Fisiologi Manusia dari Sel ke Sistem. Jakarta: ECG; 2015. p. 730.

2. James R Maulinda, MD, FACP(2018). MedScape. Goiter

https://emedicine.medscape.com/article/120034overview\#a6-Diakses pada 28 Agustus 2019.

3. Semiardji, Gatut. Penyakit Kelenjar Tiroid: Gejala Diagnosis dan Pengobatan. Jakarta: Balai Penerbit FKUI. 2008. p. 1-37.

4. Suzuki K, Kawashima A, Yoshihara A, Akama T, Sue M, Yoshida A, et al. Role of thyroglobulin on negative feedback autoregulation of thyroid follicular function and growth. J Endocrinol. 2011; 209(2):169-74.

5. Norris DO, Carr JA. The Hypothalamus-PituitaryThyroid (HPT) Axis of Mammals. Vertebr Endocrinol. 2013; 207-30.

6. WHO reaffirmsgoal for sustainable IDD elimination. In: International Centre for the control of Iodine
Deficiency Disorders (ICCIDD). IDD Newsletter 1996; 12: 1-3.

7. Brander A, Vilkinkoski P, Nickels J. Gland: US Screening Adult. Radiology. 1991;181:683-7.

8. Park JM, Choi Y, Kwag HJ. Partially cystic thyroid nodules: Ultrasound findings of malignancy. Korean J Radiol. 2012;13(5):530-5.

9. Pusdatin Kemenkes RI. Infodatin Situasi dan Analisis Penyakit Tiroid. Kemenkes RI. 2015: 3-4.

10. Kelly BS, Govender P, Jeffers $M$, et al. Risk Stratification in Multinodular Goiter: A Retrospective Review of Sonographic Features, Histopathological Results, and Cancer Risk.Can Assoc Radiol J. 2017: 425-30.

11. Anthony WG, Jill EL, Richard B, Sarah R, Jennifer P, Sogol MM, et al. Diagnostic Accuracy of Ultrasound with Color Flow Doppler in Children With Thyroid Nodules. J Clin Endocrinol Metab. 2018; 103(5): 19581965.

12. Kushchayeva YS, Kushchayev SV, Startzell M, Cochran E, Auh S, Dai Y, et al. Thyroid Abnormalities in Patients With Extreme Insulin Resistance Syndromes. The Journal of Clinical Endocrinology \& Metabolism. 2019; 104(6): 2216-2228.

13. Crosby H, Pontoh V, Merung MA. Pola Kelainan Tiroid di RSUP Prof. DR. D. R. Kandou Manado Periode Januari 2013 - Desember 2015. JurnalE-Clinic (ECI). 2016; 1 -8.

14. Tampatty G, Tubagus V, Rondo A. Profil Pemeriksaan Ultrasonografi Pada Pasien Struma di Bagian/SMF Radiologi FK UNSRAT RSUP Prof. DR. R. D. Kandau Manadoo Periode Januari 2018 - Juni 2018. Jurnal Fakultas Kedokteran Universitas Sam Ratulangi Manado. 2018: 1-6.

15. Malboosbaf R, Hosseinpanah F, Mojarrad M, Jambarsang S, Azizi F. Relationship between goiter and gender: a systematic review and meta-analysis. Springer. 2012; 43(3): 539-547

16. Fleury V, Melle GV, Woringer V, Gaillard RC, Portmann L. Sex-Dependent Variations and Timing of Thyroid Growth during Puberty. The Journal of Clinical Endocrinology \& Metabolism. 2001; 86(2): 750-754

17. Fleury V, Melle GV, Woringer V, Gaillard RC, Portmann L. Sex-Dependent Variations and Timing of Thyroid Growth during Puberty. The Journal of Clinical Endocrinology \& Metabolism. 2001; 86(2): 750-754

18. Donda A, Reymond F, Rey F, Lemarchand-Be'raud T. Sex steroids modulate the pituitary parameters involved in the regulation of TSH secretion in the rat. Acta Endocrinol (Copenh). 1990; 122: 577-584.

19. Ramey JN, Burrow GN, Polackwich RJ, Donabedian RK. The effect of oral contraceptive steroids on the response of thyroid-stimulating hormone to thyrotropin-releasing hormone. J Clin Endocrinol Metab. 1975 ; 40:712-714.

20. Maitra A, Kumar V. Kumar V, Cotran RS, Robbins SL. Robbin Buku ajar Patologi . Jakarta. EGC. 2012;2(7): hlm 818-24. 
21. Nagarkar R, Roy S, Akheel M, Palwe V, Kulkarni N, Pandit P. Incidence of thyroid disorder in India. International 7 Journal of Dental and Medical Specialty. 2015;2:19-23.

22. Assagaf SM, Lumintang N, Lampus H. Gambaran eutiroid pada pasien struma multinodusa non-toksik di bagian bedah RSUP Prof. Dr. R. D. Kandou Manado periode Juli 2012 - Juli 2014. Jurnal e-clinic. 2015;3:758- 62.

23. Tan GH, Gharib H, Reading CC. Solitary thyroid nodule. Comparison between palpation and ultrasonography. Arch Intern Med. 1995; 155: 2418-2423.

24. Firat M, Güney E, Özgen AG, Kabalak T. Comparison of Palpation and Ultrasonography in the Diagnosis of Thyroid Nodules. Turkish Journal of Endocrinology and Metabolism. 2002; 3: 117-120

25. Elahi, Shan. A study of goiter among female adolescents referred to Centre for Nuclear Medicine, Lahore. Pakistan Journal of Medical Sciences. 2005; 21: 56-62.

26. Dodd NS \& Samuel AM. Iodine deficiency in adolescents from Bombay slums. Natl Med J India 1993;6(3):110-3.

27. Moon WJ, Jung SL, Lee JH, Na DG, Baek JH, Lee YH, et al. Benign and Malignant Thyroid Nodules: US Differentiation-Multicenter Retrospective Study. Korean Society of Neuro and Head and Neck Radiology. 2008; 247(3): 762-770.

28. Polyzos SA, Kappaita M, Efstathiadou Z, Poulakos P, Slavakis A, Sofianou D, et al. Serum thyrotropin concentrasion as a biochemical predictor of thyroid malignancy in patients presenting with thyroid nodules. Journal of Cancer Research and Clinical Oncology. 2008; 134: 953-960.

29. Dauksiene D, Petkeviciene J, Klumbiene J, Verkauskiene R, Kristapone JV, Seibokaite A,et al. Factors Associated with the Prevalence of Thyroid Nodules and Goiter in Middle-Aged Euthyroid Subjects. International Journal of Endocrinology. 2017; 2017: 8 .

30. Fiore E, Rago T, Provenzale MA, Scutari M, Ugolini C, Basolo F, et al. Lower levels of TSH are associated with a lower risk of papillary thyroid cancer in patients with thyroid nodular disease: thyroid autonomy may play a protective role. Endocr Relat Cancer. 2009; 16:1251-1260 